\title{
Genetically modified foods (GMOs); a review of genetic engineering
}

\author{
Hulunim GATEW ${ }^{1 \times \square}$ and Kefale MENGISTU ${ }^{2}$ \\ ${ }^{1}$ Department of Animal Science, Debre Berhan University, P.O. Box 445, Debre Berhan, Ethiopia \\ ${ }^{2}$ Department of Veterinary Medicine, Jimma University, P.O.Box 307, Jimma, Ethiopia \\ Corresponding author's Email: hulunim@gmail.com
}

\section{ABSTRACT}

Aim. This review article mainly focuses on the importance, possible risks and state of public debate on genetic engineering particularly on genetically modified organisms (GMOs). During the last decade, tremendous progress has been made in the area of genetic engineering. The technology has numerous applications in increasing productivity of agriculture (in farm animal and plant species) and biomedical industries. Creation of resistant varieties of plants, transgenic animals, increasing the protein content, biofertilization, recombinant pharmaceuticals and gene therapy are now the major application of genetic engineering. Despite the technology has opened up new opportunities for highly specific manipulation of the genetic material of organisms, it has the possible risks of genetic contamination/inbreeding, competition with natural species, ecosystem damage, risk of horizontal gene transfer, new kinds of outbreak diseases; creation of drug resistant germs; accidental escape of laboratory strains and increased disease burden if the recipient organism is a pathogenic microorganism or virus. Additionally, now, scientists are faced with ethical issue challenges related to moral and religious acceptance and animal welfare. Conclusion. Scientists need to consider the types of applications of genetic engineering which will appear on the commercial market as well as develop procedures which will minimize potential biological and ecological hazards of the technology. Even though, genetically modified foods currently available on the international market have passed safety assessments, countries vary in their regulation of genetically modified foods indicating the necessity of worldwide consensus on labelling and traceability of genetically modified foods taking into account health and environmental risks as well as religious

Original Article

PII: S225199391900025-9

Rec. 06 June 2019

Rev. 20 November 2019

Pub. 25 November 2019

Keywords

Acceptance,

Benefits,

Biological and ecological

hazards,

Ethics,

Farm animal,

Genetically modified

organisms (GMOs),

Human healthö

Plant issues.

\section{INTRODUCTION}

Biotechnology, specifically genetic engineering is already a beneficial resource, employed in medicine, manufacturing, and agriculture. It has been started reaping the practical rewards of genetic engineering such as new medical therapies and increased agricultural yields [1].

There are many arguments in favor of the use of genetic engineering in the future. Among these are the promises that genetic engineering will feed the world, produce better crops, and be altogether good for the economy. Many different organisms are being used in today's genetic engineering research and development, including plants, trees, animals, insects, bacteria and viruses. In the agricultural sector, plants and crops are engineered to express a resistance to herbicides and specific pests. Scientists promise that genetically modified plants will have better texture, more flavor, and higher nutritional value than wild varieties of the same crops [2]. Farm animals are also modified to increase productivity and reduce costs for farmers. Pigs are engineered to have less fat, fish are being modified to grow larger more rapidly [3] and other animals are being engineered to increase productivity [4].

Although the benefits of genetically modifying organisms may seem vast, it is important to consider the fact that this is a very new technique and the risks involved are not fully understood [5]. The test subjects are living organisms, capable of growing, reproducing, migrating and interacting with other living organisms. This means that the risks involved with genetic engineering are inherently more dangerous and unpredictable than experiments using chemicals. Because of the unpredictable nature of living organisms, once a Genetically Modified Organisms (GMO) has been released into the environment, it is impossible to recall it [6]. Significant religious, secular and ethical implications ought to be taken into account as we go forward with genetic 
engineering. Genetic engineering is seen by many people as 'playing God' [4] or putting people in the place of the Creator [6] as it gives to a few people the ability to change the natural world completely. By genetically modifying organisms, a scientist assumes that this extremely new science is better for populating the world than God or any other Creator, including natural evolution and natural selection. Religious groups may have

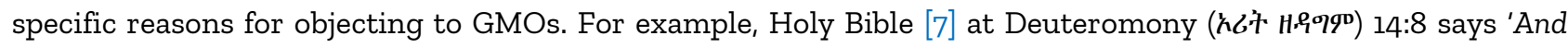
the swine, because it divides the hoof, yet chewth not the cud, it is unclean unto you: You shall not eat of their flesh nor touch their dead carcass' and The Quran also prohibits the consumption of pork in many verses including: 2:173, 5:3, 6:145 and 16:115. If the modified products are not clearly labeled as containing pig genes, vegetarians would surely object to animal genes being inserted in fruits and vegetables [2].

Therefore, the objective of this review is to address some major benefits, risks and consumers' attitude towards GMOs.

\section{DISCUSSION}

\section{Benefits of application of genetic engineering}

Genetic engineering is relatively a new laboratory technique used by scientists to change the DNA of living organism. It has already supplied us with products that alleviate illness, clean up the environment, and increased crop and livestock yields. It also helped to create thousands of organisms and processes useful in medicine, research, and manufacturing. Genetically engineered bacteria churn out insulin for treating human diabetes, production of which would be substantially more expensive without the use of genetic engineering [8].

The number of organisms used in genetic engineering research is steadily increasing, as is the number of types of animals being used in the research. Genetically engineered organisms are used in many different sectors today, including agriculture, biomedical research, and animal farming. Farm animals are modified to increase productivity and reduce costs for farmers. Pigs are engineered to have less fat, fish are being modified to grow larger more rapidly [9]. Genetic engineering holds the promise of creating new, more productive strains of farm animals for meat and milk production. These new strains may be more resistant to infections, reducing the need for large, unhealthy doses of antibiotics. They may also be engineered to produce more meat, so we need not slaughter as many animals, or they may produce milk or other products with vital nutrients otherwise not found in those products, ensuring a healthier source of such nutrients [10].

\section{Risks of application of genetic engineering}

Since the technology plays with living organisms, interacting with other living organisms the risks involved are inherently more dangerous and unpredictable than experiments using chemicals. Because of the unpredictable nature of living organisms, once a GMO has been released into the environment, it is impossible to control [11]. Genetically modified organisms are living organisms and therefore, unlike chemicals that may become diluted, GMOs have the potential to disperse to new habitats, colonize those sites, and multiply. Their novel activities, including the production of metabolic products, enzymes and toxins will occur as long as the GMOs remain metabolically active. Once established, living organisms cannot be recalled [12].

One risk associated with genetic engineering is that it is based on the idea that each trait of an organism is encoded in a single, specific gene, and that the transfer of that specific gene will also cause the transfer of the sought-after attribute. However, genes cannot be regarded as separate entities. They are all related, and they are all influenced by many factors including the external environment [13]. This means that even though a gene may be related to a specific characteristic in one organism, it may not produce the same trait in another species or even in another organism of the same species. Therefore, it is almost impossible to predict the effect that transferring a specific gene will have on the individual to which it is transferred.

\section{a) Risks to biodiversity}

The introduction of genetically modified plants into the environment may have devastating effects on biodiversity. Birds, insects, and other animals that are dependent on certain crops for survival may find themselves unable to eat the genetically engineered crops due to the introduced gene or modification [9]. They may be allergic to the new traits, or find them poisonous. Therefore, these animals would have to find other sources of food, or face starvation. This would impact the entire food chain and the predator-prey relationships. The introduction of a modified organism into the environment may cause the displacement of indigenous fauna and flora [14]. If the new strain is superior to the parent strain, it may take over the habitat or eliminate the wild 
strain. Also, any change in animal behavior could affect the entire food chain as well as predator-prey relationships [15].

\section{b) Risks of genetically modified foods}

Since the reason behind genetic engineering is basically to improve the quality of human lives, it is important to discuss the potential adverse effects that genetic engineering may have on human beings. Genetic material can enter the human body through food, bacteria, viruses, vaccines and medications. Most GMO sourced foods have a marker gene inserted in them along with the gene representing the desired trait [16]. According to theses authors, if the marker genes were transferred successfully, the organism will exhibit a new resistance to particular antibiotics. Problems could arise for humans who eat food with these genes in them, particularly if they are unaware of the presence of the genes [17]. The antibiotic resistance gene could reduce the effectiveness of any antibiotics that the person happens to be taking at the time they are eating the product. Also, if people are constantly eating food with antibiotic resistance genes in them, they could develop a resistance to antibiotics as well. There is a risk that the nutritional quality of genetically modified food will be lower than that of unmodified foods [18].

In addition to the potential problems caused by marker genes and decreasing nutritional quality, genetically modified organisms may cause allergies in many people [19]. If people are not fully aware of the nature of the food that they are eating, they may consume substances which are harmful to them. Even if a person knows that s/he should avoid a specific substance, he may not be aware that the insertion of a new gene into the product has caused the expression of a similar substance. For example, people would not expect meat genes to be inserted into tomato. If a person were allergic to meat, he may also be allergic to the tomato, without realizing that it is the same substance causing the allergic reaction. For this reason, it is important that genetically modified foods be clearly labeled.

Concerns about eating GMOs can also arise for religious reasons. According to Chaudry and Regenstein [20], some of the potential controversies that consuming such foods would create for religious persons who observe dietary laws. Jewish law (Halacha) accepts genetic engineering to increase the quality or quantity of the world's food supply. But within the Muslim world no need for genetic modification of food crops because God created everything perfectly and man does not have any right to manipulate anything that God has created using His divine wisdom. Whereas in Christianity, no overarching consensus on the permissibility of GM technology, performing of GM research, or consumption of GM foods.

\section{Consumers' attitude to GMOs}

Despite the potential benefits there is a sizeable consumer opposition to genetically modified foods and other biotechnologies. Public attitudes to the biotechnologies are related to risk. It would be comforting to think that views were made on rational evaluation of the science, but usually they are made on values and emotion. A survey of attitudes in United Kingdom (UK) to genetic modification of foods found 70\% of those questioned thought it was morally wrong. The figure was somewhat less in a United States (US) survey (45\%). However, with greater exposure of the topic in recent years, public concern seems to have increased more [21].

According to the survey conducted by Biotechnology and the European Public Concerted Action Group [22], over 16,000 people in the European Union for their opinions about the use of biotechnology for genetic testing, production of medicines and vaccines, increasing crop pest resistance, food production, developing genetically modified animals for ethics, transgenesis and xenotransplantation. Although all of these applications of biotechnology were thought to be useful, the last three, which involve genetic manipulation of animals, were viewed negatively. Perception of risk appeared to play relatively little role in this judgment, except in the case of food production. What was most important was whether or not the application of the technology was felt to be morally acceptable. The committee that interpreted the survey concluded that the results indicated that perceived usefulness was a precondition for support and that people were prepared to accept some risks for those benefits, but that moral doubts acted as a veto irrespective of views on risks and benefits.

According to Sandoe and Holtung [23], similar views were aired at a consensus conference held in Copenhagen in 1992. The welfare of genetically engineered animals was a major concern of the participants, but they also thought it morally unacceptable to induce genetic changes in animals in order to adjust the animals to existing agricultural methods or to produce cheaper food. Likewise, Hoban and Kendall [24] surveyed approximately 1300 adults in the USA followed by focus group discussions revealed that, while most believed 
that biotechnology would be personally beneficial to them, $53 \%$ also believed that it was morally wrong to use biotechnology to change animals, while only $24 \%$ believed that changing plants was wrong. The least acceptable applications of biotechnology were those that changed the composition of meat or milk, or increased animal growth rates. In the focus groups, women were particularly concerned about the humane treatment of animals and animal welfare issues arising from biotechnology.

\section{Ethical concern in genetic engineering}

Genetic engineering of a living organism may for a variety of reasons be thought of as being morally problematic in itself, i.e. due to its mode of production or to its source of genetic material be perceived as wrong or morally at least dubious. But genetic engineering may also be thought of as morally problematic because of its consequences. Kaiser [25] argued that all variants of intrinsic arguments against animal biotechnology could

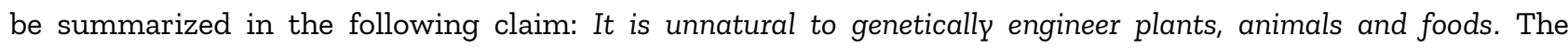
commonly most well-known argument of this sort is the so-called "Playing God-argument" [26]. The basic assumption of the argument is the following: God has drawn up invisible boundaries between the realm of God and the realm of humans. Those that transcend this boundary are guilty of hubris, i.e. excessive pride. Obviously, any such argument would also be dependent on the more specific assumptions of a religion concerning the relation of God, humans and animals. The problem is to know where this boundary is. One version of the Playing God-argument holds that it is morally wrong to break down naturally occurring boundaries between different species, and another holds that it is morally wrong to modify living nature [27].

As stated by Partridge [28] also stated that, environmental ethics is concerned with responsible personal conduct towards the environment, natural landscapes, natural resources, and all species and nonhuman organisms. According to this author, it is important to keep environmental ethics in mind when discussing genetic engineering, as many of the arguments against genetic engineering have to do with whether it is 'right' to modify organisms and the natural environment.

\section{Animal welfare in genetic engineering}

Many groups have objections to the use of animals in scientific testing. They recognize that animals have interests, and that these interests should not be violated. One argument for why animals have interests is because they have the ability to suffer [29], but wonder if animal rights should be protected at the expense of human rights [4]. As noted by Canadian Environment Network [30], "Every life form is unique, and has intrinsic value regardless of any perceived value that it may have for humans". This means that animals and plants are significant in themselves and should be treated as ends in themselves, rather than simply a means to a human end.

In Europe, the UK report an animal welfare from 1965 that became known as the Brambell report, was highly influential. Well-known "five animal freedoms" included in Brambell committee [31] are:

- Freedom from hunger and thirst by ready access to fresh water and a diet to maintain full health and vigor.

- Freedom from discomfort by providing an appropriate environment including shelter and a comfortable resting area.

- Freedom from pain, injury or disease by prevention or rapid diagnosis and treatment

- Freedom to express normal behavior by providing sufficient space, proper facilities and company of the animal's own kind.

- Freedom from fear and distress by ensuring conditions and treatment which avoid mental suffering.

\section{Objections to genetic engineering}

Some people object to any tinkering with the genetic codes of humans, or even of any life form. Some religious critics perceive genetic engineering as "playing God" and object to it on the grounds that life is sacred and ought not to be altered by human intention. Other objectors argue from secular principles, such as the outspoken and ardent Jeremy Rifkin, who claims that it violates the inherent "dignity" of humans and other lifeforms to alter their DNA under any circumstances [32]. These arguments, while perhaps well-meaning, are not supported by sound logic or empirical evidence, as will be demonstrated in Epstein [33]. Religious objections assume the existence of some creator whose will is defined by genetic engineering, and secular objections assume that life in its "natural" state, unaltered by human intention, is inviolable because of its inherent dignity. 


\section{Religious objections to genetic engineering}

Genetic engineering is seen by many people as putting people in the place of the Creator as it gives to a few people the ability to change the natural world completely. Some people hold that it is ethically questionable to transfer genes from one species to another species. This attitude is sometimes grounded in a religious belief that it is not up to humankind to violate boundaries that are set by God. Any design of nature through the insertion of new genes is, according to this argument, morally unacceptable. The argument does not occur in the Bible (in fact one may cite places to the opposite), but is based on an interpretation of God's will [20].

\section{Secular objections to genetic engineering}

Secular objectors to genetic engineering must defend the claim that the dignity of an individual member of a species, or of the species itself, is tied to its unhampered with evolution to its present state [34]. Nature itself is indifferent to our dignity, and so altering nature cannot violate our dignity. In fact, it dignifies us to use the talents we have to alter our environment and our biology to improve our lives and those of the disabled. Technology in any form is an Outgrowth of our intellectual abilities: at its best, it allows us to overcome natural shortcomings. Home heating and air conditioning violate the natural order, yet allow us to thrive in climates we otherwise could not survive. Few would argue that overcoming that natural disadvantage violates our inherent dignity.

Those who argue for drawing a line at altering the genome of humans or other organisms must give reasons both for regarding DNA as somehow special and apart from the rest of the natural world and for arguing that conscious manipulation of DNA is morally impermissible. There are some reasons to support "genetic exceptionalism," the point of view that DNA is unique, but those arguments do not necessarily imply: a) that because of this uniqueness there are absolute bars to altering it; or b) that if it is acceptable to alter the DNA of non-humans, it is nonetheless unacceptable to alter that of humans. Uniqueness does not itself imply any moral duty. In fact, every human being is "unique" by virtue of DNA, environment, and upbringing, but our moral duties toward each do not depend upon that uniqueness. Neither of the assumptions above can be sustained by logic or empirical evidence and as indicated previously, we have been tinkering with genes in plants, animals, and even human beings, through selective breeding for millennia. Thus, the uniqueness of DNA has never forbidden us implicitly or explicitly to modify what we encounter in nature [35]. It is arguably just a matter of degree rather than a qualitative difference in kind that separates selective breeding and genetic engineering. Those who oppose genetic engineering on moral grounds must make a coherent case that it is qualitatively different from selective breeding, or they must similarly oppose the selective breeding which has resulted in almost every aspect of our modern agriculture.

Rawls [36] interprets human dignity as implying that we enter into a social contract treating each individual from the position of equality: "for in this situation men have equal representation as moral persons who regard themselves as ends and the principles they accept will be rationally designed to protect the claims of their person". We have dignity in a way in which no other animal does, which is not to say that other animals lack dignity. (Creatures have their own dignity, inherent to their species and capacities).

We are the only creatures we know capable of art, science, literature, architecture, and transforming our environment to accommodate our physical limitations. The concept of human dignity is perfectly compatible with genetic engineering. Recognizing human dignity often means taking steps to ensure that where nature impedes human potential, everyone's human potential may be achieved to the fullest. The disabled and the infirm should be aided wherever possible, and consistent with their stated goals, to achieve their potential, consistent with the principle of avoiding harm to others. Indeed, recognizing the inherent dignity of our fellow human beings suggests that we are impelled to pursue genetic engineering research, to the degree that it can help to develop therapies and treatments for those who suffer or develop natural or accidental limitations [37].

Clearly, some limits on genetic engineering also may be required by human dignity. Actions that diminish the capacities of others to achieve their potential are affronts to human dignity. Genetic engineering requires special attention to issues of equal access and even some restrictions on its applications where they may threaten subordination of some humans. Any invention used to diminish critical human capacities, such as cognitive functioning, would be unethical. Thus, while some people might benefit from a small race of humans genetically engineered to be slaves with diminished mental capacities this would clearly and egregiously violate human dignity [38]. 


\section{CONCLUSION}

Agriculture and medical industry are two major applications of genetic engineering. Agriculture particularly modifying plant varieties greatly benefits from genetic engineering. Though the slogan of genetic engineering is 'feeding the world and sustainability', there are many arguments in favor use of genetic engineering in the future. Consumers have raised a series of concerns and uncertainties with regard to human health, environment, and animal welfare, moral and religious acceptances. Since genetic engineering risks involved are not well understood. The risks related to the GMOs should be studied in detail and accessed by the public. Governments in all countries should have regulations on safety issues, labelling and traceability of GMOs.

\section{DECLARATIONS}

\section{Acknowledgements}

The authors are thankful to Department of Animal Science, Debre Berhan University for providing the necessary facilities, which were used for the preparation of manuscript.

\section{Authors' contributions}

H.Gatew designed the general concept and wrote the manuscript. K.Mengistu reviewed and approved the final manuscript.

\section{Competing interests}

The authors declare that they have no competing interests.

\section{Ethics approval and consent to participate}

Not applicable.

\section{Funding}

This research work has no funding.

\section{REFERENCES}

1. Dennis ES, Ellis J, Green A, Llewellyn D, Morell M, Tabe L, and Peacock W. Genetic contributions to agricultural sustainability. Phil Trans R Soc B, 2008; 363: 445-446. http://doi.org/10.10g8/rstb.2007.2172. (Search Google Scholar ; Export Citation as EndNote)

2. Hefferon, Kathleen L. "Nutritionally enhanced food crops; progress and perspectives." Int J Mol Sci. 2015; 16(2):38953914. http://doi:10.3390/ijms16023895.

3. Epstein R. Redesigning the World: Ethical Questions about Genetic Engineering." Ethical Issues in Biotechnology. Richard Sherlock and John D. Morrey, eds. Lanham, Boulder, New York, Oxford: Rowman and Littlefield, 2002, pp.47-70. http://online.sfsu.edu/rone/GEessays/Redesigning.htm

4. Bailey, J. Genetic modification of animals: Scientific and ethical issues. In Animal Experimentation: Working towards a Paradigm Change, 2019. 443-479. https://doi.org/10.1163/9789004391192 020.

5. Bawa AS and Anilakumar KR. Genetically modified foods: safety, risks and public concerns-a review. J Food Sci Technol, 2013; 50; 1035-1046. http://doi.org/10.1007/s13197-012-0899-1.

6. Lassen J, Madsen $\mathrm{KH}$ and Sandoe P 2002. Ethics and genetic engineering - Lessons to be learned from GM foods. Bioprocess Biosyst Eng, 2002; 24:263-271. https://doi.org/10.1007/s004490100262.

7. Holy Bible English version. Deut 14:8. https://www.biblica.com/bible/

8. Wong MS, Hawthorne WJ, and Manolios N. Gene therapy in diabetes. Self Nonself, 2010; 1:165-175. http://doi.org/10.4161/self.1.3.12643

9. Louis-Marie Houdebine. Impacts of genetically modified animals on the ecosystem and human activities, Global Bioethics, 25:1, 3-18, https://doi.org/11287462.2014.894709.

10. Van Eenennaam AL. GMOs in animal agriculture: time to consider both costs and benefits in regulatory evaluations. J Anim Sci Biotechnol. 2013; 4(1). https://doi.org/10.1186/2049-1891-4-37.

11. Prakash D, Verma S, Bhatia R, and Tiwary BN. Risks and Precautions of Genetically Modified Organisms. ISRN Ecology, 2011. https://doi.org/10.5402/2011/369573.

12. Dhan Prakash, Sonika Verma, Ranjana Bhatia, and B. N. Tiwary, "Risks and Precautions of Genetically Modified Organisms," ISRN Ecology, 2011. http://dx.doi.org/10.5402/2011/369573.

13. Kathryn E, Kemper, Mike E, Goddard. Understanding and predicting complex traits: knowledge from cattle. Hum Mol Genet, 2012; 21: 45-51. https://doi.org/10.1093/hmg/dds332.

14. Bob BM. Wong and Candolin U. Behavioral responses to changing environments. Behav Ecol, 2015; 26:665-673. https://doi.org/10.1093/beheco/arul83. 
15. Calizza E, Costantini ML, and Rossi L. Effect of multiple disturbances on food web vulnerability to biodiversity loss in detritus-based systems. Ecosphere, 2015; 6:124. http://dx.doi.org/10.1890/ES14-00489.1

16. Maghari BM and Ardekani AM. Genetically Modified Foods and Social Concerns. Avicenna J Med Biotechnol, 2011; 3: 109-117. https://www.ncbi.nlm.nih.gov/pmc/articles/PMC3558185/ (Search Google Scholar ; Export Citation as EndNote)

17. Keese P. Risks from GMOs due to Horizontal Gene Transfer. Environ Biosafety Res, 2008: 7:123-149. http://dx.doi.org/10.1051/ebr:2008014.

18. Bakshi A. Potential adverse health effects of genetically modified crops. J Toxicol Env Heal B, 2003 ; 6:211-225. http://dx.doi.org/10.1080/10937400306469

19. Lee TH, Ho HK and Leung TF. Genetically modifed foods and allergy. Hong Kong Med J, 2017; 23:291-295. http://dx.doi.org/10.1280g/hkmj166189.

20. Raman, Ruchir. "The impact of Genetically Modified (GM) crops in modern agriculture: A review." GM crops \& food, 2017; 8, 4:195-208. http://dx.doi.org/10.1080/21645698.2017.1413522.

21. Rzymski P and Królczyk A. Attitudes toward genetically modified organisms in Poland: to GMO or not to GMO?" Food Sec, 2016; 8:689-697. http://dx.doi.org/10.1007/s12571-016-0572-z

22. Biotechnology and the European Public Concerted Action Group. Europe ambivalent on biotechnology. Nature, 1997; 387: 845-847. http://dx.doi.org/10.1038/43051.

23. Sandoe $P$ and Holtung N. Ethical limits to domestication. J Agric Environ Ethics, 1996; 9: 114-122. https://doi.org/10.1007/BF03055297.

24. Hoban, Thomas. Trends in consumer attitudes about agricultural biotechnology. AgBioForum, 1(1), 3-7. http://www.agbioforum.org.

25. Kaiser M. Assessing ethics and animal welfare in animal biotechnology for farm production. Rev Sci tech off int Epiz, 2005; 24:75-87. https://www.ncbi.nlm.nih.gov/pubmed/16110878.

26. Dabrock P. Playing God Synthetic biology as a theological and ethical challenge. Syst Synth Biol, $2009 ; 3: 47-54$. http://doi.org/10.1007/s11693-009-9028-5.

27. Douglas, Powell $\mathrm{R}$, and Savulescu J. Is the creation of artificial life morally significant? Stud Hist Philos Biol Biomed Sci, 2013; 44:688-696. http://doi.org/10.1016/j.shpsc.2013.05.016

28. Partridge E. Environmental Ethics: An Introduction (1980). Available at http://gadfly.igc.org/e-ethics/Intro-ee.htm.

29. Dogan A. A Defense of Animal Rights. J Agric Environ Ethics, 2010. http://doi.org/10.1007/s10806-010-9273-3.

30. Canadian Environment Network. Code of Environmental Ethics (1994). Available at http://www.royalroads.ca/ste/research/gender/Env_Code.html>.

31. Brambell committee. Report of the technical committee to enquire into the welfare of animals kept under intensive livestock husbandry systems. Command Report 2836, Her Majesty's Stationery Office (1965), London. http://edepot.wur.nl/134379.

32. Ormandy EH, Dale J, Griffin G. Genetic engineering of animals: ethical issues, including welfare concerns. Can Vet J. 2011; 52(5):544-550. https://www.ncbi.nlm.nih.gov/pmc/articles/PMC3078015/

33. Epstein R. Ethical Dangers of Genetic Engineering. Institute for World Religions (1999). Available at http://www.greens.org/s-r/20/20-01.html.

34. Rolston III and Holmes. 2002. What Do We Mean by the Intrinsic Value and Integrity of Plants and Animals? In Genetic Engineering and the Intrinsic Value and Integrity of Animals and Plants, Ed. Heaf D and Wirtz J, 2002; P.5-10, U.K. Hafan. https://mountainscholar.org/bitstream/handle/10217/39371/Ifgene-updated.pdf;sequence=1.

35. Myskaja and Bjorn K. The Moral Difference between Intragenic and Transgenic Modification of Plants. J Agric Environ Ethics, 2006; 19: 225-238. https://www.ncbi.nlm.nih.gov/pubmed/17061380.

36. Rawls J. A Theory of Justice. Cambridge MA (1999). Harvard University Press. http://www.consiglio.regione.campania.it/cms/CM PORTALE CRC/servlet/Docs?dir=docs biblio\&file=BiblioContenuto 3641.pdf

37. Bostrom N. Human Genetic Enhancements: A Transhumanist Perspective. J Value Inq, 2003 ; 37: $493-506$. https://www.ncbi.nlm.nih.gov/pubmed/17340768.

38. Cooley DR. Deaf by Design: A Business Argument against Engineering Disabled Offspring. J Bus Ethics, 2007; 71: 20927. http://doi.org/ 10.1007/s10551-006-9135-0 